Canadian Journal of Family and Youth, 13(1), 2021, pp. 84-98

ISSN 1718-9748@ University of Alberta

http://ejournals,library,ualberta.ca/index/php/cjfy

\title{
Causes and Consequences of Examination Malpractice among Senior Secondary School Students in Eti-Osa L.G.A. of Lagos State, Nigeria
}

\author{
Ifeoma P. Okafor
}

\begin{abstract}
This study investigated the causes and consequences of examination malpractice among senior secondary school students in Eti-Osa Local Government Area of Lagos State, Nigeria. A descriptive survey research method was used for the study as was a simple random sampling technique to select 540 students from twenty selected secondary schools that supplied information to the questionnaire tagged Causes and Consequences of Examination Malpractice Questionnaire (CCEMQ). The instrument was validated by experts in the Department of Social Sciences Education of University of Ilorin. The reliability of the instrument was determined using test re-test method. A reliability coefficient of 0.74 was obtained. The instrument was analysed using percentages and t-test statistics were used to test the hypotheses at a 0.05 level of significance. The findings of the study revealed that the major cause of examination malpractice was sexual harassment by teachers and the main consequence of examination malpractice was that it deprived innocent students' the opportunity for admission. Findings also revealed that there was no significant difference in the causes of examination malpractice based on gender and age. Based on the results, the researcher recommended that sound educational policy should be put in place with the de-emphasis on the supremacy of certificates over skills and professional competence. There should be improvement in the delivery of instruction especially from the foundational level to the secondary level. Also, stakeholders should stop leap services to examination malpractice.
\end{abstract}

Keywords: examination malpractice, Nigeria, sexual harassment, teachers, educational policy, causes, consequences 


\section{Okafor}

Ifeoma P. Okafor, Ph.D., a Lecturer in the Department of Social Sciences Education, University of Ilorin, Nigeria obtained her Doctor of Philosophy (Ph.D.) (2013) in Sociology of Education from the University of Ilorin, Nigeria. Okafor is a registered teacher with the Teachers' Registration Council of Nigeria (TRCN). She is a member, Association of Sociologists of Education in Nigeria, member, Social Studies Association of Nigeria, and Member, History of Education Society of Nigeria. Recent publications include: Okafor, I. P. (2020). Causes and consequences of drug abuse among youth in Kwara State, Nigeria. Canadian Journal of Family and Youth, 12(1), 147-162. (A Journal of the University of Alberta). Available online at http://ejournals,library,ualberta.ca/index/php/cjfy; Okafor, I. P. (2020). Influence of domestic violence on girl-child academic performance of students in Itesiwaju Local Government Area, Oyo State, Nigeria. Anatolian Journal of Education, 5(1), 119-124. (A Journal of the Faculty of Education, Eskisehir Osmangazi University, Turkey). Available online at http://eaje.net/images/dosyalar/aje 2020 1 11.pdf; and Iyekolo, A. O., Okafor, I. P. \& Abdulaziz, I. (2020). Attitude of teachers towards women leadership of secondary schools in Ilorin, Kwara State. Anatolian Journal of Education, 5(1), 135-140. (A Journal of the Faculty of Education, Eskisehir Osmangazi University, Turkey). Available online at http://e-aje.net/images/dosyalar/aje_2020_1_13.pdf 
Okafor

\section{Introduction}

An examination is the main yardstick used for the measurement of a learner's achievement. Examinations on a wider perspective are used as an instrument for academic stratification, assessing grades, evaluating and accreditation. The end product of such a judgment is used for diagnosing placement, guidance, and certification. Examinations are also used to choose those who intend to enter into government services, state schools, and some other educational institutions.

The bodies for these examinations are the West African Examinations Council (WAEC), the National Examinations Council (NECO), the Joint Admissions and Matriculation Board (JAMB), and the National Business and Technical Education Board (NABTEB). Examinations are either public or external and they are carried out on behalf of the state with opportunities given to those who meet the criteria (George \& Ukpong, 2013; Akanni \& Odofin, 2015). Public examinations provide an adequate basis for qualifying students' abilities and also to exert control over the attainment of the curricula across schools. Moreover, public examinations are different from school examinations, which are more or less internal or school-based, in which case the teachers, are directly involved in the assessment of their students. School-based examinations include continuous assessment, terminal, and promotion examinations.

In Nigeria, all of the stakeholders of education and learners place their judgments concerning the quality of educational outcomes (most of the time) on performance at public examinations (Anzene, 2014). Public examinations, therefore, seem to be the most popular parameter by which society judges the products of its educational system. This is because performance in public examinations is now used as a prerequisite for admission into other levels of schooling, job placements, and awards of certificate and diploma (Emiukwu, 2012; Asore, 2014; Adegboyega, Okesina, \& Jacob, 2017).

Examinations can be used to classify students into those with higher and lower abilities. Those with high abilities have a performance level above those with low abilities. (Of course, those with low abilities desire to have a higher performance level). This type of grading encourages some students to engage in examination malpractice in order to obtain good results. As such, to demonstrate that they too have high abilities, they take part in all kinds of vices, including examination malpractice (Idahosa, 2014). Examination malpractice can be seen as any irregular behaviour (that contravenes examination rules and regulations) exhibited by a candidate or anybody charged with this type of conduct before, during, or after an examination. In Nigeria, examination malpractice has continued to appear in different forms including the sale of examination question papers, the smuggling of relevant text materials into examination halls, impersonation, disorderliness in examination halls, and forgery of result slips (Uzoigwe, 2014; Nnam \& Inah, 2015). Generally, it is believed that it is not only students who are involved in these acts. Parents, teachers, school heads, and examination officials, all collude with students to perpetrate this misconduct and the collusion between one or more of these agents makes it more difficult to combat (Joshua, Oba, Joshua, Edet \& Ekpoh, 2010; Onyechere, 2014). 
Examination malpractice has become prevalent within all levels of Nigeria's educational systems. To buttress this point, the West African Examination Councils (WAEC) Chief Examiner reported in 2006, that in Nigeria between May/June 1996 and May/June (2005) a total of 1,367,726 of students representing $9.4 \%$ were involved in examination malpractice. This large figure shows how widespread the menace of examination malpractice has eaten into the very fabric of the educational system (Onuka \& Durowoju, 2013).

However, various methods have been adopted by different examination bodies at the federal, state and local government levels to seize perpetrators of examination malpractice. Some of these efforts include checking the passport of the candidate sitting for the examination, prohibiting the use of electronic devices (such as GSM and pagers), questioning unannounced visits to examination centres by examination officers, and prohibiting answers written on papers other than ones provided. Such efforts hamper those involved by discountenance or cancelling their results (due to mass cheating) (Onyibe, Uma \& Ibina, 2015).

Examination malpractice has proven to be a tug of war in the Nigerian educational system and this has caused some examination to lose credibility and expose the entire educational system to ridicule, to the extent that many students cannot defend their certificates and are not employable. This is why this researcher has embarked on this research, in order to discover the causes and consequences of examination malpractice among senior secondary school students in Eti-Osa Local Government Area of Lagos State, Nigeria.

\section{Statement of the Problem}

Examination malpractice has become a serious problem in the Nigerian educational system. Onyibe, Uma and Ibina (2015) researched examination malpractice in Nigeria and its causes effects on national development. Akanni and Odofin (2015) also worked on reducing examination malpractice in Nigerian schools through effective Continuous Assessment (C.A.) techniques as an alternative to one-shot examinations in Osun State, Nigeria. Asore (2014) likewise carried out research on examination malpractice including its causes, consequences and probable solutions. All of these research works are position papers and some of them are foreign based, however this present research is empirical and considers senior secondary schools in the Eti-Osa Local Government Area of Lagos State, Nigeria. In particular, it highlights the causes and consequences of examination malpractice.

\section{Research Questions}

1. What are the causes of examination malpractices among secondary school students in the Eti-Osa Local Government Area of Lagos State?

2. What are the consequences of examination malpractices among secondary school students in the Eti-Osa Local Government Area of Lagos State? 


\section{Research Hypotheses}

The following research hypotheses were formulated for the study:

Ho1: There is no significant difference in the causes of examination malpractice among secondary school students in the Eti-Osa Local Government Area of Lagos State based on gender.

Ho2: There is no significant difference in the consequences of examination malpractice among secondary school students in the Eti-Osa Local Government Area of Lagos State based on gender.

Ho3: There is no significant difference in the causes of examination malpractice among secondary school students in the Eti-Osa Local Government Area of Lagos State based on age.

Ho4: There is no significant difference in the consequences of examination malpractice among secondary school students in the Eti-Osa Local Government Area of Lagos State based on age.

\section{Methodology}

The research design used in this study was a descriptive survey with a target population of 540 from 20 selected secondary schools. 27 respondents were selected from each school using random sampling techniques. A self-developed instrument titled the "Causes and Consequences of Examination Malpractice Questionnaire' (CACOEMQ) was used to collect the data. The CACOEMQ has 15 items and two sections; Section A and B. Section A relates to the demographic data of the respondents and section B contains the variables on causes and consequences of examination malpractices. The instruments were validated by experts in test construction and measurement from the University of Ilorin and a reliability coefficient of 0.76 was established. Rank order was used to test the research questions while t-test was used to analyse the research hypotheses at a 0.05 level of significance.

\section{Results}

The results obtained from the data analyzed are presented and all the hypotheses formulated for this study were subjected to independent t-test statistics and tested at a 0.05 level of significance using the Statistical Package for Social-Sciences (SPSS 23.0). 


\section{Okafor}

Demographic Description of the Respondents

The data presented in Table 1 shows the demographic characteristics of the respondents using percentages.

Table 1: $\quad$ Distribution of the Respondents by Gender, Age, Class, Religion

\begin{tabular}{ccc}
\hline Variables & Frequency & Percentage (\%) \\
Gender & 225 & 41.7 \\
Male & 315 & 58.3 \\
Female & $\mathbf{5 4 0}$ & $\mathbf{1 0 0 . 0}$ \\
Total & & \\
Age & 268 & 49.6 \\
10 - 15 years & 272 & 50.4 \\
16 years and Above & $\mathbf{5 4 0}$ & $\mathbf{1 0 0 . 0}$ \\
Total & & \\
& & \\
Class & 123 & 22.8 \\
SSS I & 254 & 47.0 \\
SSS II & 163 & 30.2 \\
SSS III & $\mathbf{5 4 0}$ & $\mathbf{1 0 0 . 0}$ \\
Total & & \\
Religion & 330 & 61.1 \\
Christian & 210 & $\mathbf{1 0 0 . 0}$ \\
Muslim & $\mathbf{5 4 0}$ & \\
Total & & \\
\hline
\end{tabular}

Source: Field Survey, 2018

Table 1 revealed that out of the 540 respondents that participated in the study, 225 of them (representing $41.7 \%$ of the respondents) were male, while 315 (representing $58.3 \%$ of the respondents) were female. This implies that there were more female respondents than male respondents in this study.

In addition, Table 1 revealed that out of the 540 respondents that participated in the study, 268 (representing $49.6 \%$ of the respondents) were between the ages $10-15$ years, while 272 (representing 50.4\% of the respondents) were between the ages 16 years and above. This shows that the majority of the respondents in this study were between the ages 16 years and above. 


\section{Okafor}

Furthermore, Table 1 revealed that out of the 540 respondent that participated in the study, 123 (representing $22.8 \%$ of the respondents) were Senior Secondary School (SSS) I students, 254 (representing 47.0\%) of the respondents) were SSS II students, while 163 (representing $30.2 \%$ of the respondents) were SSS III students. This implies that there were more respondents from SSS II in this study.

Additionally, Table 1 revealed that out of the 540 respondents that participated in the study, 330 (representing $61.1 \%$ of the respondents) were Christians while 210 (representing $38.9 \%$ of the respondents) were Muslims. This implies that there were more respondents that were Christians than Muslims in this study.

\section{The Research Questions Answered}

Six research questions were raised and answered in this study. Research questions 1 and 2 were answered using a mean rating, while research questions 3 to 6 (that had a corresponding hypothesis) were tested with the use of the independent t-test statistical tool.

Research Question 1: What are the causes of examination malpractice in secondary schools in the Eti-Osa Local Government Area of Lagos State?

Table 2: Ranking Order of causes of examination malpractice in secondary school in the EtiOsa Local Government Area of Lagos State

\begin{tabular}{|c|c|c|c|}
\hline $\mathbf{S} / \mathbf{N}$ & Items & Mean & Ranking \\
\hline 15 & Sexual harassment by teachers can lead to examination malpractice & 3.32 & $1^{\text {st }}$ \\
\hline 14 & $\begin{array}{l}\text { Inadequate teacher student's interaction can lead to examination } \\
\text { malpractice }\end{array}$ & 3.23 & $2^{\text {nd }}$ \\
\hline 13 & $\begin{array}{l}\text { Extortion of money from student by invigilators can lead to } \\
\text { examination malpractice }\end{array}$ & 3.10 & $3^{\text {rd }}$ \\
\hline 4 & Students laziness can promote examination malpractice & 2.72 & $4^{\text {th }}$ \\
\hline 5 & Negative peer influence can bring about examination malpractice & 2.72 & $4^{\text {th }}$ \\
\hline 12 & $\begin{array}{l}\text { Inadequate funding in school and teacher's welfare can encourage } \\
\text { examination malpractice }\end{array}$ & 2.66 & $6^{\text {th }}$ \\
\hline 3 & $\begin{array}{l}\text { Inability to get reading materials in the library can make students } \\
\text { indulge in examination malpractice }\end{array}$ & 2.57 & $7^{\text {th }}$ \\
\hline 6 & $\begin{array}{l}\text { Too much involvement in social activities can make students } \\
\text { engage in examination malpractice }\end{array}$ & 2.53 & $8^{\text {th }}$ \\
\hline 9 & Frequent strike actions can lead to examination malpractice & 2.52 & $9^{\text {th }}$ \\
\hline 8 & $\begin{array}{l}\text { Using students to mark students' scripts can lead to examination } \\
\text { malpractice }\end{array}$ & 2.40 & $10^{\text {th }}$ \\
\hline 1 & $\begin{array}{l}\text { Poor attendance by teachers can make students indulge in } \\
\text { examination malpractice }\end{array}$ & 2.31 & $11^{\text {th }}$ \\
\hline 2 & Inadequate preparations for examination by the students can cause & 2.27 & $12^{\text {th }}$ \\
\hline
\end{tabular}




\section{Okafor}

examination malpractice

10 Collaboration between staff and students in relation to marks can

lead to examination malpractice

11 Improper structure of examinations can lead to examination malpractice

7 Inadequate concern for student's welfare and activities can lead to examination malpractice

Source: Field Survey, 2018

Table 2 indicates that 540 respondents participated in this study. The major causes of examination malpractice in secondary schools in the Eti-Osa Local Government Area of Lagos State was 'sexual harassment by teachers can lead to examination malpractice' which has a mean score of $3.32\left(1^{\text {st }}\right)$, 'inadequate teacher students' interaction can lead to examination malpractice' which has a mean score of $3.23\left(2^{\text {nd }}\right)$, and 'extortion of money from students by invigilators can lead to examination malpractice' which has a mean score of $3.10\left(3^{\text {rd }}\right)$.

Also, 'student laziness' can promote examination malpractice and 'negative peer influence can bring about examination malpractice' both of which have a mean score of 2.72 $\left(4^{\text {th }}\right)$. 'Inadequate funding' in school and teachers welfare can encourage examination malpractice' has a mean score of $2.66\left(6^{\text {th }}\right)$, 'inability to get reading materials in the library can make students indulge in examination malpractice' which has a mean score of $2.57\left(7^{\text {th }}\right)$, and 'too much involvement in social activities can make students engage in examination malpractice' has a mean score of $2.53\left(8^{\text {th }}\right)$. 'Frequent strike actions can lead to examination malpractice' has a mean score of $2.52\left(9^{\text {th }}\right)$, while other statements have a mean score below the 2.50 benchmark.

\section{Research Question 2: What are the consequences of examination malpractice in secondary school in the Eti-Osa Local Government Area of Lagos State?}

Table 3: Ranking Order of Consequences of Examination Malpractice in Secondary School in the Eti-Osa Local Government Area of Lagos State

\begin{tabular}{clcc}
\hline S/N & \multicolumn{1}{c}{ Items } & Mean & Ranking \\
\hline 2 & $\begin{array}{l}\text { Examination malpractice deprives an innocent student's opportunity } \\
\text { for admission }\end{array}$ & 3.39 & $\mathbf{1}^{\text {st }}$ \\
1 & $\begin{array}{l}\text { Examination malpractice discourages good students from studing } \\
\text { hard }\end{array}$ & 3.26 & $\mathbf{2}^{\text {nd }}$ \\
3 & $\begin{array}{l}\text { Students with examination malpractice results in decreased job } \\
\text { efficiency }\end{array}$ & 2.95 & $\mathbf{3}^{\text {rd }}$ \\
5 & $\begin{array}{l}\text { Examination malpractice renders the goals of education invalid } \\
\text { Examination malpractice leads to dissatisfaction on the part of the } \\
\text { candidates }\end{array}$ & 2.89 & $\mathbf{4}^{\text {th }}$ \\
\hline
\end{tabular}

Source: Field Survey, 2018 


\section{Okafor}

Table 3 indicates that 540 respondents participated in this study. The main consequences of examination malpractice in secondary school in the Eti-Osa Local Government Area of Lagos State was that 'examination malpractice deprives an innocent student's opportunity for admission' which has a mean score of $3.39\left(1^{\text {st }}\right)$, 'examination malpractice discourages good students from studying hard' has a mean score of $3.26\left(2^{\text {nd }}\right)$ while 'students with examination malpractice results in decreased job efficiency' has a mean score of $2.95\left(3^{\text {rd }}\right)$. 'Examination malpractice renders the goals of education invalid' has a mean score of 2.89 ( $\left.4^{\text {th }}\right)$, while 'examination malpractice leads to dissatisfaction on the part of the candidates' has a mean score of $2.67\left(5^{\text {th }}\right)$.

\section{Hypotheses Testing}

Having considered the demographic data of the respondents and answering research questions, the researcher proceeded to test the null hypothesis generated in the study. The research hypothesis postulated for this study was tested using the independent t-test statistics at a 0.05 level of significance.

\section{Ho1: There is no significant difference in the causes of examination malpractice in secondary school in the Eti-Osa Local Government Area of Lagos State based on gender.}

In order to test this research hypothesis, respondent's responses on the causes of examination malpractice questionnaire were collated based on gender. The data collected from the study was analyzed as shown in Table 4.

Table 4: Mean, Standard Deviation and t-test Analysis of Difference in the Causes of Examination Malpractice in Secondary School in the Eti-Osa Local Government Area of Lagos State based on Gender

\begin{tabular}{|c|c|c|c|c|c|c|c|}
\hline Gender & $\mathbf{N}$ & Mean & SD. & Df & Cal.t & Sig. (2-tailed) & Decision \\
\hline Male & 255 & 37.61 & 10.79 & 520 & 165 & 011 & $\mathrm{H}_{01}$ \\
\hline Female & 315 & 39.39 & 11.43 & & & & \\
\hline
\end{tabular}




\section{Okafor}

As shown on Table 4, male respondents had a mean score of 37.61 with a standard deviation of 10.79, while female respondents had mean score of 39.39 with a standard deviation of 11.43. The calculated t-value was 1.65 , while its calculated significance value was 0.11 of $\mathrm{df}$ $2 / 538$ at alpha level of 0.05 . On this basis, null hypothesis one was therefore not rejected. This means that there was no significant difference in the causes of examination malpractice in secondary school in the Eti-Osa Local Government Area of Lagos State based on gender. The reason was that the calculated significance value $(0.11)$ was greater than 0.05 alpha level $(\rho>$ $0.05)$.

Ho2: There is no significant difference in the consequences of examination malpractice in secondary school in the Eti-Osa Local Government Area of Lagos State based on gender.

In order to test this research hypothesis, respondent's responses on the Consequences of Examination Malpractice Questionnaire were collated based on gender. The data collected from the study was analyzed as shown in Table 5.

Table 5: $\quad$ Mean, Standard Deviation and t-test Analysis of Difference in the Consequences of Examination Malpractice in Secondary School in the Eti-Osa Local Government Area of Lagos State based on Gender

\begin{tabular}{lccccccc}
\hline Gender & N & Mean & SD. & df & Cal.t & Sig. (2-tailed) & Decision \\
\hline Male & 225 & 15.18 & 2.99 & 538 & 0.11 & 0.92 & $\begin{array}{c}\text { Ho2 } \\
\text { Fot Rejected }\end{array}$ \\
\hline Female & 315 & 15.15 & 3.33 & & & &
\end{tabular}

As shown on Table 5, male respondents had a mean score of 15.18 with a standard deviation of 2.99, while female respondents had a mean score of 15.15 with a standard deviation of 3.33 . The calculated t-value was 0.11 , while its calculated significance value was 0.92 of df 2/538 at alpha level of 0.05 . On this basis, null hypothesis two was therefore not rejected. This means that there was no significant difference in the consequences of examination malpractice in secondary schools in the Eti-Osa Local Government Area of Lagos State based on gender. The reason was that the calculated significance value (0.92) was greater than 0.05 alpha level $(\rho>0.05)$. 


\section{Okafor}

Ho3: There is no significant difference in the causes of examination malpractice in secondary school in the Eti-Osa Local Government Area of Lagos State based on age.

In order to test this research hypothesis, respondent's responses on the Causes of Examination Malpractice Questionnaire were collated based on age. The data collected from the study was analyzed as shown in Table 6.

Table 6: $\quad$ Mean, Standard Deviation and t-test Analysis of Difference in the Causes of Examination Malpractice in Secondary School in the Eti-Osa Local Government Area of Lagos State based on Age

\begin{tabular}{|c|c|c|c|c|c|c|c|}
\hline Age & $\mathbf{N}$ & Mean & SD. & df & Cal.t & Sig. (2-tailed) & Decision \\
\hline $10-15$ years & 268 & 39.05 & 11.41 & & & & $\mathrm{H}_{03}$ \\
\hline 16 yrs and Above & 272 & 38.23 & & 538 & 0.76 & 0.45 & Not Rejected \\
\hline
\end{tabular}

As shown on Table 6, respondents between the ages of $10-15$ years had a mean score of 39.05 with a standard deviation of 11.41 , while respondents between the age 16 years and above had a mean score of 38.23 with a standard deviation of 10.97 . The calculated t-value was 0.76 , while its calculated significance value is 0.45 of $\mathrm{df} 2 / 538$ at an alpha level of 0.05 . On this basis, null hypothesis three was therefore not rejected. This means that there was no significant difference in the causes of examination malpractice in secondary schools in the Eti-Osa Local Government Area of Lagos State based on age. The reason was that the calculated significance value $(0.45)$ was greater than the 0.05 alpha level $(\rho>0.05)$.

Ho4: There is no significant difference in the consequences of examination malpractice in secondary school in the Eti-Osa Local Government Area of Lagos State based on age.

In order to test this research hypothesis, respondent's responses on the Consequences of Examination Malpractice Questionnaire were collated based on age. The data collected from the study was analyzed as shown in Table 7. 
Okafor

Table 7: $\quad$ Mean, Standard Deviation and t-test Analysis of Difference in the Consequences of Examination Malpractice in Secondary School in the Eti-Osa Local Government Area of Lagos State based on Age

\begin{tabular}{|c|c|c|c|c|c|c|c|}
\hline Age & $\mathbf{N}$ & Mean & SD. & df & Cal.t & Sig. (2-tailed) & Decision \\
\hline $10-15$ years & 268 & 15.37 & 3.21 & & & & $\mathrm{H}_{04}$ \\
\hline 16 years and Above & 272 & 14.95 & 3.16 & & & & \\
\hline
\end{tabular}

As shown on Table 7, respondents between ages $10-15$ years had a mean score of 15.37 with a standard deviation 3.21, while respondents between the ages 16 years and above had a mean score of 14.95 with a standard deviation of 3.16. The calculated t-value was 1.38 while its calculated significance value was 0.17 of df $2 / 538$ at an alpha level of 0.05 . On this basis, null hypothesis four was therefore not rejected. This means that there was no significant difference in the consequences of examination malpractice in secondary school in the Eti-Osa Local Government Area of Lagos State based on age. The reason was that the calculated significance value (0.17) was greater than the 0.05 alpha level $(\rho>0.05)$.

\section{Discussion of the Findings}

This study investigated the causes and consequences of examination malpractice in secondary schools in the Eti-Osa Local Government Area, Lagos State. From the analysis presented, the following discussions of the findings were made.

The findings of this study revealed that the major causes of examination malpractice in secondary school in Eti-Osa Local Government Area of Lagos State was sexual harassment by teachers. This finding supports that of Oko and Adie (2016) who in their studies reported that an array of factors were responsible for examination malpractice in Nigeria which included what most respondents called the "wrong value system which leads to serious quests for certification instead of knowledge and skills", These factors included laziness, a lack of preparation or inadequate preparation for the examination, a lack of self-confidence, poor school facilities, poor invigilation, and weak parental factors. Another finding revealed that the main consequences of examination malpractice in secondary schools in the Eti-Osa Local Government Area of Lagos State was that examination malpractice deprives an innocent student's opportunity for admission. This finding is congruent with that of Uzoigwe (2014 and Oko and Adie (2016) who found that candidates/students who would ordinarily be working hard to pass their examinations now depend on quick arrangements since they believe so much in such arrangements as they rarely failed. 


\section{Okafor}

Findings further revealed that there was no significant difference in the causes of examination malpractice in secondary schools in the Eti-Osa Local Government Area of Lagos State based on gender. This finding is congruent with that of Emaikwu (2012) and Petters and Okon (2013) who reported that there was no significant difference in the male and female causes of examination malpractice in secondary schools in Nigeria.

Furthermore, findings revealed that there was no significant difference in the consequences of examination malpractice in secondary schools in the Eti-Osa Local Government Area of Lagos State based on age. This finding corroborates with that of Ojonemi, Enejoh, Enejoh and Olatunmibi (2013). These researchers found that there was no significant difference in the consequences of examination malpractice in secondary school on the basis of age.

\section{Recommendations}

The following recommendations were made based on the findings of the study.

1. A change in the value system. The situation where people place so much value on certification does not augur well for our academics as it encourages examination malpractice. Sound educational policy should be put in place with a de-emphasis on the supremacy of certificates over skills and professional competence.

2. It is recommended that there should be an improvement in the delivery of instruction especially at the foundation (i.e. at the primary and secondary levels).

3. Stakeholders in education should be firm in instilling moral values in their children and wards to avoid examination malpractice at all levels of education.

4. Teachers and supervisors should be persons of proven integrity. The invigilators should be very vigilant in the supervision of examinations and should be fair to all. The question of double standards should not arise.

\section{Conclusion}

In conclusion, the findings of this study revealed that the major causes of examination malpractice in secondary schools in the Eti-Osa Local Government Area of Lagos State was that sexual harassment by teachers can lead to examination malpractice. Another finding revealed that the main consequences of examination malpractice in secondary schools in the Eti-Osa Local Government Area of Lagos State was that examination malpractice deprives an innocent student's opportunity for admission.

Findings further revealed that there was no significant difference in the causes of examination malpractice in secondary schools in the Eti-Osa Local Government Area of Lagos State based on gender and age. 


\section{References}

Adegboyega, L. O., Okesina, F. A. \& Jacob, O. A. (2017). Family relationship and bullying behaviour among students with disabilities in Ogbomoso, Nigeria. International Journal of Instruction, 10(3), 241-256.

Ahmed, B.U (2009). Trends in Examination Malpractice: A Statistical Analysis. Paper Presented at the National Conference on Examination Ethics, Abuja. Retrieved March 11, 2016, from http://www.academicjournals.org/ijpe/pdf/.

Akanni, O.O., \& Odofin, B. (2015). Reducing Examination Malpractices in Nigerian Schools through Effective Continuous Assessment (C.A) Techniques as an Alternative to oneshot examination in Osun State, Nigeria. American Journal of Educational Research, 2(1): 91-101.

Akaranga, S.I, \& Ongong, J.J (2013). The Phenomenon of Examination Malpractice: An Example of Nairobi and Kenyalta Universities Journal of Education and Practice, 4(18): 87-96.

Alutu, A.N \& Aluede, O. (2009). Secondary School Students' Perception of Examination Malpractices and Examination Ethics. Retrieved February 14, 2011 from http://www.krepublisher.co/02-journals/IJES/

Anzene, S.J (2014). Trends in Examination Malpractice in Nigerian Educational System and its Effects on the Socio-Economic Development of Nigeria. Asian Journal of Humanities and Social Sciences, 2(3):1-8.

Asore, E.P. (2014). Examination Malpractice: Causes, Consequences and Probable Solutions. https://patriciaglobalissues.wordpress'com/201407/19/31/

Badejo, A.O \& Gandonu, M.G. (2010). Predisposing Factors Inwards Examination Malpractices among Students in Lagos University: Implication for Counselling. Retrieve June, 18, 2014 from http//www.naero.orglindex.phplnacro-journey/

Emaikwu, S. O. (2012). Assessing the impact of examination malpractices on the measurement of ability in Nigeria. International J. Soc. Sci. \& Education, 2(4), $748-757$.

Emaikwu, S.O. \& Eba, E. (2007). Examination malpractices in tertiary institutions: Implications and the way forward. In Akubue, A.U. \& Enyi, D. (Ed.) (389-400) Crises and Challenges in Higher Education in Developing Countries. A Publication of the Department of Educational Foundations, University of Nigeria, Nsukka.

George, I.N, \& Ukpong, D.E (2013). Contemporary Social Problems in Nigeria and its Impact on National Development: Implication for Guidance and Counselling Services. Journal of Education and Social Research, 3(2): 167-173.

Idahosa, M.C (2014). Perceived Causes of Malpractice in Public Examinations by Fresh Students of St. Augustine's College of Education, Akoka Lagos, Retrieved June 30, 2016, from http://www.academicjournals.org/IJPC/pdf/

Jimoh, B.O (2009). Examination Malpractice in Secondary Schools in Nigeria: What Sustain it? Retrieved July 30, 2016, from htpp://ozalacademy.com/EJESVIN3 


\section{Okafor}

Joshua, M.T, Obo, F.E, Joshua, A.M, Edet, AO., \& Ekpoh, U.I (2010). Perception of Examination Malpractice and Intervention Strategies by some Stakeholders in the Nigerian School System. Journal of Educational Assessment in Africa. 4, 255-268.

Nnam, M.U., \& Inah, A.F (2015). Empirical Investigation into the Causes, Forms and Consequences of Examination Malpractice in Nigerian Institute of Higher Learning International Journal of Novel Research in Humanity and Social Sciences 2(1): 52-62.

Ojonemi, P. S., Enejoh, W., Enejoh, A., \& Olatunmibi, O. (2013). Examination malpractice: Challenges to human resource development in Nigeria. International Journal of Capacity Building in Educationand Management, 2(1), 91 - 101.

Ojonemi, P.S., Enejoh, W., Enejoh, A., \& Olatunmibi, O. (2013). Examination Malpractice: Challenges of Human Resource Development in Nigeria: International Journal of Capacity Building in Education and Management, 2(1): 91-101.

Oko, S. U. \& Adie, R. I. (2016). Examination malpractice: Causes, effects and possible ways of curbing the menace. A study of Cross River University of Technology. International Journal of Managerial Studies and Research (IJMSR), 4(1), 59-65, ISSN2349-0330 PRINT\&ISSN 2349-0349 onlinewww.arcjournal.orgOnuka, A.O.U, \& Durowoju, E.O (2013). Stakeholders Role in Curbing Examination Malpractice in Nigeria. International Journal of Economy Management and Social Sciences, 2(6): 342-348.

Onyechere, I. (2014). Examination Fraud. Retrieved June 18, 2016 from http://www.egoboosterbooks-files.wordpress.com

Onyibe, C.O, Uma, U.U. and Ibina, E. (2015). Examination Malpractice in Nigeria: Causes and Effects on National Development in Journal of Education and practice. ISSN 2222288+online vol. 6. no. 26, 2015.

Petters, J.S, \& Okon M.O (2013). Students' Perception of Causes and Effects of Examination Malpractice in the Nigerian Educational System: The Way Forward for Quality Education. Retrieved from the Nigerian Education System: The way forward for Quality Education. Retrieved fromhttp://news2.onlinenigeria.com/news/general/5692-exammalpractice-implication-for-national-development.html

The CWO Voice (06/04/2010). Examination malpractice: Implication for National Development. Retrieved from http://news2.onlinenigerian.com/news/general/5692exam-malpracticeimplication-for-national-development.html

Uzoigwe, G.O. (2014). Corruption in education and assessment systems: The WAEC experience in Nigeria. Retrieved from www.iaea.info/documents/paper-1162dib538.pdf. 